Joyful Learning Journal

\title{
KEEFEKTIFAN MODEL MAKE A MATCH BERBANTUAN KARTU BERGAMBAR TERHADAP HASIL BELAJAR IPA
}

\section{Eva Dian Wahyu Sulistyaningkrum ${ }^{凶}$, Desi Wulandari}

Jurusan Pendidikan Guru Sekolah Dasar, Fakultas Ilmu Pendidikan, Universitas Negeri Semarang, Indonesia

\begin{abstract}
Info Artikel
Sejarah Artikel:

Diterima April 2020

Disetujui Mei 2020

Dipublikasikan Juni 2020

Keywords: Learning outcomes; Picture

Card; Make a

Match

Abstrak

Rendahnya kualitas pendidikan disebabkan oleh hasil belajar siswa di beberapa mata pelajaran yang terbilang rendah. Hal tersebut didukung oleh data hasil belajar PAS IPA siswa kelas IV SDN Gugus Diponegoro Kabupaten Pati yang terbilang rendah. Salah satu penyebabnya adalah kurang mengetahui model yang cocok digunakan saat pembelajaran. Tujuan penelitian ini adalah untuk menguji keefektifan model make a match berbantuan kartu bergambar terhadap hasil belajar ipa siswa kelas IV SDN Gugus Diponegoro Kabupaten Pati. Penelitian ini menggunakan metode kuantitatif dan jenis penelitian quasi eksperimen. Sampel penelitian ini adalah kelas IV SDN Tambahmulyo 01 sebanyak 18 siswa dan kelas IV SDN Tambahmulyo 02 sebanyak 14 siswa sebagai kelas eksperimen, kelas IV SDN Sonorejo sebanyak 26 siswa dan kelas IV SDN Kedungmulyo sebanyak 18 siswa sebagai kelas kontrol. Data hasil belajar dianalisis menggunakan uji-t untuk menguji perbedaan rata-rata kelas kontrol dan kelas eksperimen. Hasil perhitungan menggunakan Independent sample t-test menunjukkan jika nilai (2tailed) $<0,05$,karena hasil penelitian menunjukkan bahwa kolom (2-tailed) yaitu sebesar 0,000 yang berarti lebih kecil dari 0,05. Simpulan dari penelitian ini adalah model make a match berbantuan kartu bergambar efektif digunakan dalam pelajaran IPA. Saran guru dan siswa diharapkan untuk menerapkan model pembelajaran Make a Match berbantuan kartu bergambar dalam pembelajaran di kelas dan untuk agar dapat meningkatkan hasil belajar siswa sehingga mutu sekolah meningkat.
\end{abstract}

\begin{abstract}
The low quality of education was caused by student learning outcomes in several subjects that are fairly low. This was supported by the data on learning outcomes of the PAS IPA fourth-grade Diponegoro Elementary School in Pati Regency which is relatively low. One of the reasons is not knowing the suitable model to use when learning. The purpose of this study is to test the effectiveness of the models make a match aided by picture cards on the learning outcomes of the fourth-grade students of the Diponegoro Elementary School in Pati Regency. This research used quantitative methods and quasi-experimental research types. The sample of this research divided into 2 clusters, both of the clusters was taken at the fourth-grade. Tambahmulyo 01's Elementary School (18 students) and Tambahmulyo 02's Elementary School (14 students) were as an experimental class, Sonorejo Elementary School (26 students), and Kedungmulyo Elementary School (18 students) were as a control class. Learning outcomes data were analyzed by using a t-test to test the difference in the average of the control class and the experimental class. The results of the Independent sample t-test indicate if the value $(2$-tailed $)<0.05$, due to the results of the study indicate the column (2-tailed) is equal to 0,000 which means it is smaller than 0.05. The conclusion of the research from the models make a match aided by picture cards is effectively used in science lessons. The suggestions for teachers and students are expected to apply the Model of Make a Match aided by picture cards in classroom learning and improved the school quality by improving the students learning outcomes.
\end{abstract}

(C) 2020 Universitas Negeri Semarang 


\section{PENDAHULUAN}

Pendidikan merupakan kebutuhan hidup manusia mutlak yang harus dipenuhi demi tercapainya tujuan hidup. Untuk mencapai tujuan yang diprogramkan, pendidikan melibatkan beberapa komponen yang bekerjasama. Salah satunya yaitu pada mata pelajaran IPA di SD yang bertujuan supaya siswa dapat mengembangkan rasa ingin tahu, mengembangkan keterampilan proses untuk menyelidiki alam sekitar, mengembangkan pengetahuan dan pemahaman konsep-konsep IPA yang akan bermanfaat dan dapat diterapkan dalam kehidupan sehari-hari. In the 2013 Curriculum, the competence expected from an SD / MI graduate is to have a productive and creative thinking and acting abstract and concrete.In Indonesia, the science content taught integratedly is physics, biology, chemistry and astronomy. Dalam Undang-Undang Nomor 20 tahun 2003 Bab I Pasal 1 tentang Sistem Pendidikan di Indonesia, menyatakan bahwa pendidikan adalah usaha sadar dan terencana untuk mewujudkan suasana dan proses pembelajaran sehingga peserta didik dapat aktif mengembangkan potensi dirinya untuk memiliki kekuatan spiritual keagamaan, pengendalian diri, kepribadian, kecerdasan, akhlak mulia, serta keterampilan yang diperlukan dirinya, masyarakat, bangsa dan negara.

Sedangkan menurut Undang - Undang Nomor 24 tahun 2016 BAB 1 Pasal 1 menyatakan bahwa pelaksanaan pembelajaran pada Sekolah Dasar / Madrasah Ibtidaiyah (SD/MI) dilakukan dengan pendekatan pembelajaran tematik terpadu, kecuali untuk mata pelajaran Matematika dan Pendidikan Jasmani Olahraga dan Kesehatan (PJOK) sebagai mata pelajaran yang berdiri sendiri untuk kelas IV,V,VI. Data collection techniques used in this research method documentation, observation, and question form. Nilai-nilai ipa kurang maksimal, kurangnya media sebagai alat pembelajaran yang digunakan, model pembelajaran yang dipilih oleh pengajar belum sesuai dengan materi yang ada.

Data tersebut didukung dengan data hasil belajar PAS IPA kelas IV SDN Gugus Diponegoro Tahun Ajaran 2019/2020 dari jumlah siswa sebanyak 118 siswa, 78 siswa $(66,1 \%)$ hasil belajar IPA masih di bawah KKM dan sisanya 40 siswa $(33,8 \%)$ sudah di atas KKM yaitu 70. Djamarah (2013: 108) menyatakan jika pembelajaran bisa dinyatakan berhasil apabila mencapai $75 \%$ atau lebih dari jumlah peserta didik yang mengikuti proses kegiatan pembelajaran mencapai taraf keberhasilan, dan apabila masih belum mencapai batas tersebut maka langkah yang harus diambil yaitu melakukan program perbaikan atau remidial.

Berdasarkan permasalahan mengenai pembelajaran IPA tersebut peneliti ingin menguji
Keefektifan Model pembelajaran berbantuan media. Model yang dipilih untuk penelitian ini yakni Model Make a Match berbantuan Kartu bergambar. Dengan menggunakan metode Make A Match siswa akan lebih aktif dalam pembelajaran dan siswa dapat belajar dengan situasi yang lebih menarik.

Penelitian yang hampir sama dengan penelitian kai ini antara lain penelitian yang dilakukan oleh oleh $\mathrm{Km}$. Evita Wulandari, dkk (2017) hasil yang didapat menunjukkan bahwa hasil uji-t, diperoleh bahwa thitung adalah 4,34 sedangkan ttabel pada taraf signifikan $5 \%$ dan db 47 adalah 2,0117. Disamping itu, rata-rata skor hasil belajar ipa kelompok siswa yang dibelajarkan dengan model make a match berbasis penilaian portofolio $(23,174)$ lebih tinggi dari pada rata-rata skor kelompok siswa yang dibelajarkan dengan pembelajaran konvensional $(17,846)$.Beragam penelitian terdahulu memberikan gambaran bahwa pentingnya model pembelajaran inovatif untuk diteliti. Sehingga penelitian kali ini bertujuan untuk menguji keefektifan model make a match berbantuan kartu bergambar terhadap hasil belajar ipa siswa kelas IV di SDN Gugus Diponegoro Kabupaten Pati.

\section{METODE PENELITIAN}

Jenis penelitian ini adalah penelitian eksperimen yang mengarah pada hubungan sebab akibat pada dua variabel tau lebih dengan treatment. Desain penelitian Eksperimen diantaranya meliputi: Pre Experimental design, The Experimental Design, Factorial Design, Quasi Experimental design (Sugiyono 2015:108).

Populasi yang diambil dalam penelitian mencakup semua siswa kelas 4 SDN Gugus Diponegoro Kabupaten Pati yang terdiri atas 7 sekolah,yaitu sebagai berikut:

Tabel 1. Data Siswa Kelas IV SDN Gugus Diponegoro Kabupaten Pati

\begin{tabular}{clc}
\hline No. & \multicolumn{1}{c}{ Nama Sekolah } & Jmlh siswa kls IV \\
\hline 1 & SDN Tlogorejo & 18 \\
& SDN Tambahmulyo & 18 \\
2 & 01 & 14 \\
& SDN Tambahmulyo & 18 \\
3 & 02 & 9 \\
4 & SDN Kedungmulyo & 26 \\
5 & SDN Ngastorejo & 15 \\
6 & SDN Sonorejo & 118 \\
7 & SDN Sendangsoko & \\
\hline & & \\
\hline
\end{tabular}

Variabel pada penelitian ini meliputi variabel bebas, variabel terikat, dan variabel kontrol. Variabel bebas dalam penelitian ini 
adalah Model Make a Match berbantuan Kartu Bergambar, sedangkan variabel terikat dari penelitian ini yaitu hasil belajar IPA. Dan variabel kontrolnya adalah Kemampuan belajar, keadaan sekolah, fasilitas dan sarana prasarana sekolah, materi pelajaran, latar belakang pendidikan guru, serta pengalaman mengajar guru yang relatif sama. Teknik analisis terdiri dari analisis data awal dan analisis data akhir. Analisis data awal yaitu uji normalitas dan uji homogenitas, sedangkan analisis data akhir yaitu uji normalitas, homogenitas, uji hipotesis dan uji n-gain.

\section{HASIL DAN PEMBAHASAN}

Penelitian ini bertujuan untuk mengetahui model pembelajaran make a match berbantuan kartu bergambar terhadap hasil belajar IPA siswa kelas IV. Model pembelajaran kooperatif tipe make a match ini merupakan tipe pembelajaran yang memberikan satu kartu soal atau jawaban kepada setiap siswa, lalu siswa mencari pasangan dari setiap kartu soal atau jawaban yang dipegangnya. Setelah satu babak, kartu dikocok lagi agar setiap siswa mendapat kartu yang berbeda dari sebelumnya. Hasil dari penelitian ini dapat dilihat dari nilai pretest dan posttest. Pretest dan posttest merupakan sebuah dasar untuk melihat keefektifan model make a match berbantuan kartu bergambar yang diukur dalam ranah kognitif peserta didik. Pretest yang diterapkan di kelas kontrol dan ekperimen sebelum diterapkannya treatment ini digunakan untuk mengetahui kesamaan pengetahuan awal peserta didik,sedangkan untuk menarik kesimpulan berdasarkan hipotesis penelitian menggunakan nilai posttest yang diberikan kepada kedua kelas tersebut.

Tabel 2. Hasil Belajar IPA

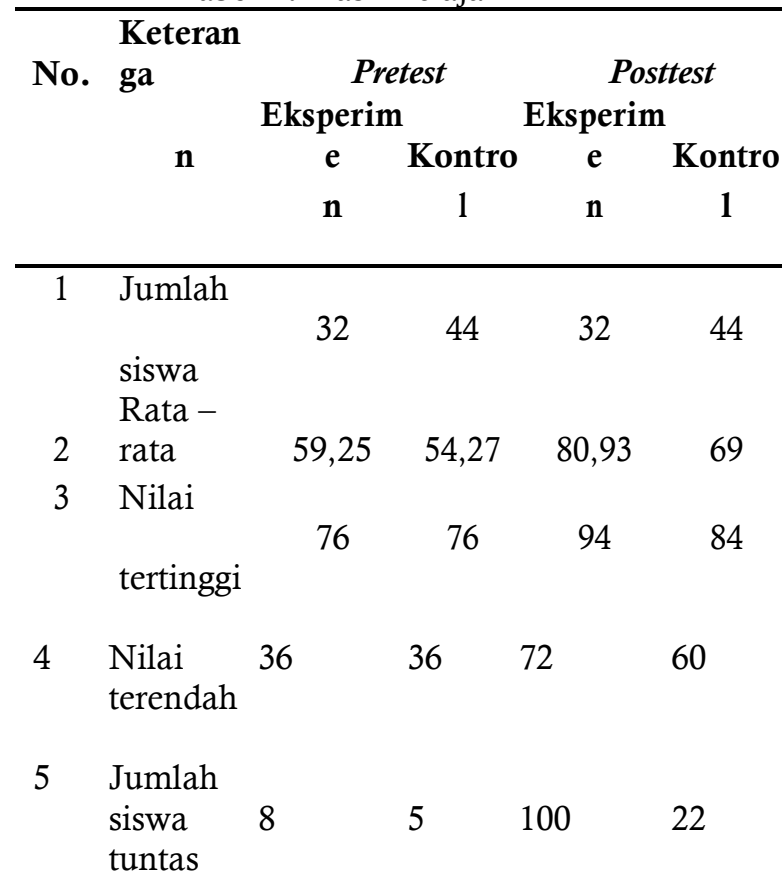

Ketuntas
a $25 \%$
n belajar

Berdasarkan hasil pretest dan posttest yang telah disajikan dalam tabel maka dapat dilihat bahwa kemampuan awal peserta didik yang didapat dari pengambilan nilai pretest dari kedua kelas kontrol dan eksperimen memiliki rata-rata yang hampir sama, rata-rata nilai pretest pada kelas kontrol ialah 54,27 sedangkan rata-rata pretest pada kelas ekperimen adalah 59,25. Akan tetapi hasil nilai posttest dari kedua kelas tersebut terlihat memiliki selisih, rata-rata nilai posttest pada kelas kontrol yaitu 69, sedangkan hasil nilai posttest kelas eksperimen adalah 80,93. Terlihat terjadinya peningkatan yang cukup tinggi pada kelas ekperimen.

Dengan hal ini maka dapat disimpulkan bahwa nilai posttest yang diperoleh kelompok kelas eksperimen yang menerapkan model make a match berbantuan kartu bergambar lebih tinggi jika dibandingkan dengan kelas kontrol. Setelah mendapatkan data seperti pada tabel 2. maka selanjutnya mencari hasil perhitungan uji normalitas data pretest pada kelas kontrol menggunakan uji Kolmogorov Smirnov dengan bantuan SPSS versi 25. Kriteria pengujiannya adalah data dapat dikatakan normal jika signifikansi>0,05 (Ha diterima), sebaliknya jika data signifikansi<0,05 (Ha ditolak) data tidak berdistribusi normal. Berdasarkan hasil perhitungan uji normalitas data pretest pada kelas eksperimen dan kelas kontrol menggunakan uji Kolmogorov Smirnov diperoleh hasil Asymp. Sig.(2-tailed) sebesar 0,200>0,05 maka dapat diambil kesimpulan $\mathrm{Ha}$ diterima dan data berdistribusi normal.

Berdasarkan hasil perhitungan uji homogenitas data nilai pretest SDN Gugus Diponegoro menggunakan uji one way anova dengan bantuan SPSS versi 25. Pada kelas eksperimen dengan kelas kontrol diperoleh hasil signifikansi>0,05 $(0,093>0,05)$ maka $\mathrm{Ha}$ diterima. Kesimpulan yang didapatkan berdasarkan hasil perhitungan uji homogenitas bahwa $\mathrm{Ha}$ diterima sehingga data nilai pretest kelas eksperimen dan kelas kontrol memiliki varian yang sama atau homogen.

Perhitungan uji normalitas pada data posttest pada kelas kontrol menggunakan uji Kolmogorov Smirnov dengan bantuan SPSS versi 25, dan bisa dikatakan normal apabila signifikansi $>0,05$ dan data posttest menunjukan $0,200>0,05$. Dengan demikian dapat disimpulkan bahwa Ha diterima dan H0 ditolak, sehingga analisis data posttest pada kelas eksperimen dan kelas kontrol berdistribusi normal. Berdasarkan hasil perhitungan uji homogenitas data nilai posttest menggunakan uji one way ANOVA dengan bantuan SPSS versi 25. Pada kelas eksperimen dan kelas kontrol 
diperoleh signifikansi $>0,05$ yaitu $(0,739>0,05)$ ,maka Ha diterima. Berdasarkan uji homogenitas dapat disimpulkan jika Ha diterima sehingga data nilai posttest kelas eksperimen dan kelas kontrol memiliki varian yang sama atau homogen.

Tabel 3 Uji Independent Sample T-Test

\begin{tabular}{|c|c|c|c|c|c|c|c|c|c|c|}
\hline & & $\mathrm{F}$ & Sig. & $t$ & df & $\begin{array}{c}\text { Sig.( } \\
2 . \\
\text { taile } \\
\text { d) }\end{array}$ & $\begin{array}{c}\text { Mean } \\
\text { differe } \\
\text { nce }\end{array}$ & $\begin{array}{c}\text { Std. } \\
\text { error } \\
\text { differe } \\
\text { nce }\end{array}$ & $\begin{array}{c}\text { Lowe } \\
\mathrm{r}\end{array}$ & Upper \\
\hline Nila & Equal & 4.23 & .04 & 6.98 & 74 & .000 & 11.937 & 1.7089 & 8.532 & 15.34 \\
\hline \multirow[t]{7}{*}{$\mathrm{i}$} & $\begin{array}{c}\text { varian } \\
\text { ces } \\
\text { assum }\end{array}$ & 7 & 3 & 5 & & & 50 & 5 & 34 & 266 \\
\hline & ed & & & & & & & & & \\
\hline & $\begin{array}{l}\text { Equal } \\
\text { varian }\end{array}$ & & & $\begin{array}{c}7.37 \\
1\end{array}$ & $\begin{array}{c}73.9 \\
48\end{array}$ & .000 & $\begin{array}{c}11.937 \\
50\end{array}$ & $\begin{array}{c}1.6194 \\
2\end{array}$ & $\begin{array}{c}8.710 \\
69\end{array}$ & $\begin{array}{c}15.16 \\
431\end{array}$ \\
\hline & ces & & & & & & & & & \\
\hline & not & & & & & & & & & \\
\hline & assum & & & & & & & & & \\
\hline & ed & & & & & & & & & \\
\hline
\end{tabular}

Hasil perhitungan menggunakan Independent Sample T-Test menujukan jika nilai (2tailed) $<0,05$, karena dalam tabel 3. diatas menunjukan bahwa kolom (2- tailed) yaitu sebesar 0,000 yang berarti lebih kecil dari 0.05 ,maka dapat dibaca jika terdapat perbedaan yang siginifikan antara hasil belajar kelas eksperimen dan kelas kontrol. Dengan demikian dapat disimpulkan bahwa model pembelajaran make a match berbantuan kartu bergambar lebih efektif terhadap hasil belajar IPA siswa kelas IV SDN Gugus Diponegoro.

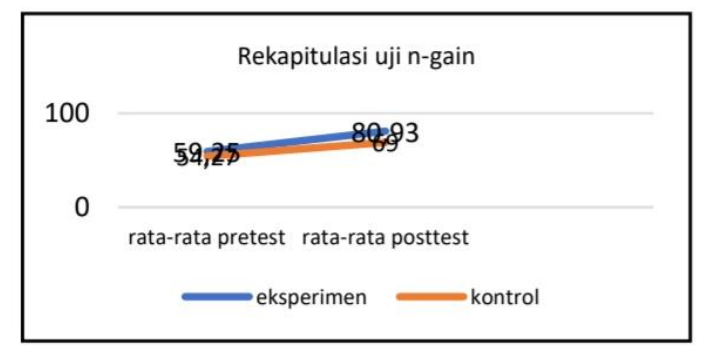

Gambar 1. Diagram Peningkatan Rata-rata Hasil Belajar IPA Siswa Kelas IV SDN Gugus Diponegoro

Berdasarkan gambar 1. yang telah disajikan maka dapat dilihat bahwa kemampuan awal yang dimiliki peserta didik dalam kelas kontrol dan kelas eksperimen hampir sama. Hal ini dibuktikan hasil perhitungan nilai pretest pada kedua kelas, yaitu kelas kontrol memiliki ratarata 54,27 dan kelas ekperimen memiliki 59,25. Setelah diberi perlakuan berupa model pembelajaran make a match berbantuan kartu bergambar, maka diperoleh hasil belajar IPA siswa kelas IV materi gaya di kelas eksperimen lebih meningkat dibandingkan dengan kelas kontrol, dengan rincian pada kelas kontrol dan kelas ekperimen mempunyai selisih rata-rata nilai posttest yang cukup jauh. Yaitu pada kelas kontrol mendapatkan rata-rata skor posttest 69, dan kelas eksperimen mendapatkan rata-rata skor posttest
80,93. Penyebap meningkatnya aktivitas siswa dengan menggunakan model Make A Match sesuai dengan ciri-ciri pembelajaran Make $A$ Match yaitu menekankan pada aktivitas siswa secara maksimal untuk mencari dan menemukan sendiri inti dari materi itu sendiri.

Tabel 4. Uji n-gain

\begin{tabular}{lcc}
\hline \multicolumn{1}{c}{ Kelas } & N-gain score & Kriteria \\
\hline Kontrol & 0,28 & Rendah \\
Eksperimen & 0,49 & Sedang \\
\hline
\end{tabular}

Nilai n-gain yang didapat dari kelas eksperimen lebih tinggi jika dibandingkan nilai ngain di kelas kontrol. Nilai n-gain kelas kontrol yaitu 0,28 termasuk dalam kriteria rendah, dan nilai n-gain kelas eksperimen adalah 0,49 termasuk dalam kriteria sedang. Berdasarkan hasil pretest dan posttest dengan berbagai perhitungan yang telah dilaksanakan tersebut menunjukkan peserta didik pada kelas eksperimen dengan penerapan model make a match berbantuan kartu bergambar memiliki peningkatan hasil belajar lebih tinggi daripada siswa kelas kontrol.

Hasil penelitian tersebut sejalan dengan hasil penelitian terdahulu yang pernah dilakukan oleh peneliti sebelumnya terkait dengan model pembelajaran make a match, diantaranya adalah penelitian eksperimen yang dilakukan oleh Nurul Hasanah (2018) dengan judul "Pengaruh Metode Eksperimen Terhadap Pemahaman Siswa Tentang Gaya Dapat Mengubah Gerak Suatu Benda".Bahwa penggunaan metode eksperimen terhadap siswa kelas IV A SDN 2 Cibunigeulis Kecamatan Bungursari Kota Tasikmalaya, dapat meningkatkan pemahaman siswa lebih baik dibandingkan dengan metode konvensional. Kelas eksperimen memperoleh rata-rata indeks gain yaitu 0,5341 dengan kategori sedang, sedangkan kelas kontrol yaitu 0,2178 dengan kategori rendah. Dapat dilihat bahwa rata-rata indeks gain kelas eksperimen yaitu 8,92 lebih tinggi daripada rata-rata indeks gain kelas kontrol yaitu 3,39. Sehingga dapat disimpulkan bahwa peningkatan pemahaman konsep siswa dengan menggunakan metode eksperimen lebih tinggi dibandingkan dengan menggunakan metode konvensional.

Penelitian oleh Mawardi dan Desty Lusia S. dengan judul "Keefektifan Model Pembelajaran Picture And Picture dan Make a Match Ditinjau Dari Hasil Belajar Dalam Pembelajaran IPA Kelas 4 SD Gugus MawarSuruh". Bahwa hasil penelitian yang telah dilakukan menunjukkan bahwa tidak terdapat perbedaan yang signifikan terhadap model pembelajaran Picture and Picture dan Make a Match ditinjau dari hasil belajar IPA pada SD gugus 
Mawar Suruh. Hal tersebut dapat dibuktikan setelah dilakukan uji t posttest yang menunjukkan bahwa nilai t hitung dan t tabel adalah 0,538 dan 1,994 dengan sig. (2-tailed) adalah 0,592.

Penelitian yang dilakukan oleh A. Raymundus R, Hery Kresnadi, dan Mastar Asran dengan judul "Penggunaan Metode Eksperimen Dalam Pembelajaran IPA Untuk Meningkatkan Hasil Belajar Siswa di Sekolah Dasar". Bahwa penggunaan metode eksperimen dalam pembelajaran Ilmu Pengetahuan Alam untuk meningkatkan hasil belajar peserta didik di kelas VI Sekolah Dasar Negeri 30 Labos Kec.Jelimpo dapat dilihat dari (1) Hasil belajar siswa dalam pembelajaran Ilmu Pengetahuan Alam menggunakan metode eksperimen pada siklus I siswa yang tuntas hanya 7 orang dan pada siklus II menjadi 12 orang dengan nilai yang memuaskan. Dengan rata-rata pada siklus I adalah 63,57. Dan rata-rata nilai pada silkus II menjadi 90. Terjadi peningkatan sebesar 26,43.

\section{SIMPULAN}

Simpulan dari penelitian yang dilakukan di SDN Gugus Diponegoro Kabupaten Pati, bahwa Model Make a Match efektif untuk meningkatkan hasil belajar IPA siswa kelas IV. Perbedaan hasil kognitif terlihat dari hasil pretest dan posttest yang dilaksanakan sebelum dan sesudah pembelajaran (treatment) pada kelas kontrol dan kelas eksperimen. Berdasarkan hasil perhitungan pada kelas eksperimen terlihat perkembangan yang cukup baik yaitu dari nilai rata-rata pretest 59,25 meningkat menjadi 80,93. Sedangkan yang didapatkan dari kelas kontrol ,rata-rata pretest 54,27 meningkat menjadi 69. Penerapan Model Make a Match berbantuan kartu bergambar mengarah kearah positif dan terbukti lebih unggul dibandingkan dengan model pembelajaran yang biasa diajarkan oleh pengajar, dan cocok diterapkan pada materi gaya di kelas IV SDN Gugus Diponegoro Kabupaten Pati.

\section{UCAPAN TERIMA KASIH}

Peneliti mengucapkan terima kasih kepada kedua orang tua yang selalu memberikan doa dan dukungan. Dosen pembimbing, Desi Wulandari, S.Pd., M.Pd. serta mitra bestari Drs. A. Busyairi, M.Ag. dan Moh. Fathurrahman, S.Pd., M.Sn. yang telah memberikan bimbingan dan masukan dalam penyusunan manuskrip ini.

\section{DAFTAR PUSTAKA}

Cahyani, Isah. 2017. Using of Experiential Learning Model Based on Multimedia to Increase the Ability of Literation Writing Indonesian Poem in Elementary School. International Journal of Active Learning, 2(1): 28 .
Fauzi, Mohamad. 2017. The Effect of Make a Match (MAM) Type Model and Bamboo Dance Type Model Through Cooperative Learning on Students Motivation. Suska Journal of Mathematics Education, 3(1): 28.

Fitriani, N. 2016. The Effectiveness of CTL Model Guided Inquiri-Based In The Topic Of Chemicals In Daily Life To Improve Students' Learning Outcomes And Activeness. Jurnal Pendidikan IPA Indonesia, 5(2): 279

Hasanah, Nurul. 2018. Pengaruh Metode Eksperimen Terhadap Pemahaman Siswa Tentang Gaya Dapat Mengubah Gerak Suatu Benda. Jurnal Ilmiah Pendidikan Guru Sekolah Dasar, 5(1): 128.

Herisnawati. 2015. Pengaruh Metode Make a Match Terhadap Aktivitas, Minat dan Hasil Belajar Siswa Pada Pembelajaran IPA. Jurnal Pengkajian Ilmu dan Pembelajaran Matematika dan IPA IKIP Mataram, 3(2):100.

Indriati, D. 2012. Meningkatkan Hasil Belajar IPA Konsep Cahaya Melalui Pembelajaran Science-Edutainment Berbantuan Media Animasi. Jurnal Pendidikan IPA Indonesia, 1(2): 192.

Mawardi. 2015. Keefektifan Model Pembelajaran Picture And Picture dan Make a Match Ditinjau Dari Hasil Belajar Dalam Pembelajaran IPA Kelas 4 SD Gugus Mawar-Suruh. Jurnal Scholaria, 5(3): 125.

Raymundus, A. 2015. Penggunaan Metode Eksperimen Dalam Pembelajaran IPA Untuk Meningkatkan Hasil Belajar Siswa di Sekolah Dasar. Jurnal Pendidikan dan Pembelajaran Khatulistiwa, 4(12): 2.

Tobing, Lolya. 2015. Perbedaan Model Pembelajaran Kooperatif Tipe Think Pair Share (TPS) dan Make a Match (MaM) Terhadap Hasil Belajar Siswa Pada Materi Ekosistem di Kelas X SMA Negeri 6 Medan T.P 2014/2015. Jurnal Pelita Pendidikan, 3(4): 122.

Wulandari, Evita. 2018. Pengaruh Model Pembelajaran Make a Match Berbasis Penilaian Portofolio Terhadap Hasil Belajar IPA. Journal of Education Action Research, 2(3): 241.

Zuliana, Anis. 2015. Meningkatkan Hasil Belajar IPA Melalui Metode Make a Match Tema Peduli Makhluk Hidup Di Sekolah Dasar. Jurnal PGSD, 3(2): 1573. 